\title{
FIELD PERFORMANCE OF A WINGED SCARIFIER AS A FUNCTION OF SOIL COMPACTION AND WATER CONTENT
}

\author{
Carmen Cholaky $^{1 *}$, José M. Cisneros ${ }^{1}$, and Roberto Balbuena ${ }^{2}$
}

\begin{abstract}
Initial soil conditions, operational aspects, and tool shape affect the efficiency of soil decompaction. The objective of this study was to evaluate the performance of a winged scarifier as a function of soil compaction and edaphic water content. The experiment was carried out in a typical Hapludoll. Treatments considered two soil compaction levels: high (HC) and low compaction (LC); and three soil water contents: wet (WS), humid (HS), and dry (DS) with 9, 14, and 19\% gravimetric water content, respectively. A split-plot randomized block design was applied. Tractive effort, disturbed area, tillage depth, specific resistance, and power were evaluated. Results showed that tractive effort was $17 \%$ greater in HC than LC, and in both cases HS was greater than WS and DS. The specific resistance in $\mathrm{HC}$ was equal to 8,9 , and $11 \mathrm{~N} \mathrm{~cm}^{-2}$ in WS, $\mathrm{HS}$, and DS, respectively, and 7, 8, and $7 \mathrm{~N} \mathrm{~cm}^{-2}$ in $\mathrm{BC}$ in similar soil water contents, respectively. Tillage depth was low and irregular only in HC-DS. Specific resistance was not an adequate indicator of overall work efficiency because it does not consider the final soil physical profile. Overall work efficiency in $\mathrm{HC}$ was greater under HS conditions, while in LC it was greater under HS and DS conditions.
\end{abstract}

Key words: agricultural engineering, winged scarifier, bulk density, water content, compaction.

\section{INTRODUCTION}

Degradation and deterioration of physical and chemical soil properties is apparent in practically all agricultural land used for crops in Argentina (SAGyP-CFA, 1995). In accordance with the experiments carried out by numerous authors, the sustained increase of the cultivated area using conservationist farming systems has not been managed to revert this tendency, especially in the physical properties, visualizing superficial and sub-superficial topsoil compaction processes (Ressia et al., 2000; Uberto et al., 2004).

There are diverse processes in soils under production that are shown as mitigating factors of compaction. Some of these cycles are self-structuring profile processes, such as humidification-drying, freeze-melt, biological activity, and the generation of pores by the roots. To these, we

${ }^{1}$ Universidad Nacional de Río Cuarto, Facultad de Agronomía y Veterinaria, Ruta Nacional 36, km 601, Río Cuarto (X5804BYA), Córdoba, Argentina.

"Corresponding author (ccholaky@ayv.unrc.edu.ar).

${ }^{2}$ Universidad Nacional de La Plata, Facultad de Ciencias Agrarias y Forestales, Av. 60 y 119, La Plata (1900), Argentina.

Part of this information was presented in the XVIII Congreso de la Ciencia del Suelo, 2002, Puerto Madryn, Argentina.

Received: 28 May 2008.

Accepted: 10 November 2008. can add strategies for crop rotation, incorporation of organic matter, planning of mechanized tasks, and the use of decompacters. Some of the "natural" factors are not present in many regions and in these situations, and if there are compaction problems, mechanical decompaction constitutes one of the main technological alternatives (Balbuena et al., 2009).

The main design characteristics of the diverse farming devices for soil fragmentation have considered tillage depth, active element width, wings, and incidence angle (Desbiolles et al., 1997; Godwin, 2007). Cisneros et al. (1998) adapted a winged decompacter called "zero plowshare", originally developed to fragment soil densifications with hydrohalomorphic display without clod or soil alteration, to loosened hardened layers in normal soils. Di Prinzio et al. (2001) observed that the disturbed area of densified soil increased with the incorporation of winged plowshares in the bottom part of a subsoiler combined with chisels, and without increasing fuel consumption when compared to the subsoiler without wings. Godwin (2007) states that adding wings modifies the way soil is disturbed, duplicating soil area disturbed and increasing tractive force by only $30 \%$ with regard to a tool without wings. According to the author, this implies that the effectiveness of the operation increases when the specific resistance decreases in a ratio of around $30 \%$. 
In accordance with the above-mentioned author, decreasing the horizontal force does not constitute the main objective pursued in tillage, but instead, turns out to be more significant and is a better indicator of the overall tillage result which is to reduce the magnitude of specific resistance (tractive force/disturbed area ratio).

With regard to the efficiency of tillage carried out with rigid and flexible chisel arcs, Di Prinzio et al. (1999) evaluated the tillage energy coefficient with the product of the mean weighted diameter of aggregates produced by the tillage operation and operational power, observing that the chisel with rigid arcs used energy more rationally than flexible arcs. Camacho-Tamayo and Rodríguez (2007) showed results with a similar tendency and observed a lower specific resistance in tillage done with a rigid chisel than with a vibratory chisel.

Water content incidence and soil density when carrying out different tillage operations have been studied in diverse types of soils. With regard to water content, Camacho-Tamayo and Rodríguez (2007) evaluated the performance of the tillage implements at different water contents $(5,12$, and $15 \%)$ of loam soil and observed that the intermediate water content was the adequate condition to till the soil owing to the fact that it generated lower specific resistance, a lower power requirement, and greater disturbed soil area than the rest of the conditions. Similar tendencies were observed by Arvidsson et al. (2004), who evaluated the specific resistance of primary tillage implements on soils with different textures in dry, humid, and wet conditions, observing a direct and close relationship between the studied variable and soil cohesion, and that the specific resistance increased as soil water content decreased, clearly showing that the maximum fragmentation of clods is produced in the intermediate humidity level.

Sasaki et al. (2007) evaluated ideal water content to carry out a subsoiling operation in soils of different textures and observed an inverse relationship between the disturbed soil area by tillage and the humidity increase at the time of the operation. Cholaky et al. (2002) observed that tillage with a winged subsoiler generated high fragmentation of the profile independently of the original compaction level, and when tillage was carried out in friable soil conditions, a greater degree of profile fracture was produced.

Mouazen and Ramon (2002) established relationships between the tractive effort of a rigid subsoiler and water content, soil bulk density and tillage depth of a sandy loam soil. They observed that tractive force increased in a nonlinear way as tillage depth and soil bulk density increased, while it decreased linearly with the increase of water content that the profile showed at tillage. This decrease was produced at up to a water content of $0.17 \mathrm{~m}^{3} \mathrm{~m}^{-3}$. The higher the water content, tractive effort was higher or lower, and the differences in tractive effort between 0.17 and $0.22 \mathrm{~m}^{3}$ $\mathrm{m}^{-3}$ of water in the soil were small. Mouazen et al. (2002) and Mouazen (2002), working on the same soil as the previous authors, evaluated the effect of soil water content and soil bulk density on cohesion and internal friction angle between soil particles. They observed that cohesion increased with soil bulk density in all the evaluated water contents that fluctuated between 3 and $22 \%$. The rate of increase of cohesion with soil bulk density decreased as water content increased.

The hypothesis of this study was that soil water content and compaction influence the performance and tillage energy efficiency with a winged scarifier. The objective was to evaluate the work capacity of this tool in different compaction degrees and soil water contents when carrying out the tillage operation.

\section{MATERIALS AND METHODS}

The area under study is located in the Tercero Arriba Department (32 $46^{\prime}$ S, 634' W), Province of Córdoba, Argentina. The climate of the region is temperate with mean temperatures of $23.7{ }^{\circ} \mathrm{C}$ and $9.6{ }^{\circ} \mathrm{C}$ in the warmest month (January) and the coldest month (July), respectively. The precipitation regime is monsoon-like with a total annual mean of $779 \mathrm{~mm}$, of which $80 \%$ is distributed in the spring and summer months with a high intensity. Winds are relevant in August and September due to their high intensity and frequency (Agencia Córdoba AmbienteINTA, 2006). Soil of the experimental site is a typical Hapludoll with a very fine sandy loam texture (Table 1).

Two experimental variables were considered: compaction level and soil water content at tillage. Regarding the first, two situations were evaluated: 1) low compaction (LC) that presented an accumulated 4-yr effect of loosening with the "zero plowshare" winged scarifier (Cisneros et al., 1998), subsequently 2-yr without any type of intervention, and 2) high compaction (HC), situation under direct sowing during the same period as the previous with a uniformly compacted horizon and which had no prior decompaction tillage. Soil bulk density values (BD) are shown in Table 2. It must be noted that in $\mathrm{LC}$, the $12-28 \mathrm{~cm}$ thickness showed two mean BD values due to the fact that in the same thickness sectors co-exist where the effect of decompaction tillage (lower value) persisted with others, where there was recompaction of the layer previously loosened (higher value).

In relation to the mean gravimetric water content of the first $40 \mathrm{~cm}$ soil depth at tillage, three conditions were considered: dry soil with hard consistence (DS), humid with friable consistence (HS), and wet with a slightly plastic consistence (WS), with 9, 14, and 19\% water, respectively. 
Table 1. Soil properties of the experimental site at the soil depth affected by tillage.

\begin{tabular}{|c|c|c|c|c|}
\hline \multirow[b]{2}{*}{ Soil properties } & \multicolumn{4}{|c|}{ Soil depth (cm) } \\
\hline & $0-6$ & $6-12$ & $13-28$ & $28-40$ \\
\hline Organic matter, $\%$ & 1.42 & 1.13 & 1.12 & 0.86 \\
\hline \multicolumn{5}{|l|}{ Granulometry, \% } \\
\hline Clay $(<2 \mu)$ & 13.47 & 15.83 & 16.20 & 14.59 \\
\hline Lime $(2-50 \mu)$ & 32.28 & 31.56 & 30.78 & 30.08 \\
\hline Very fine sand $(50-250 \mu)$ & 44.92 & 42.92 & 45.05 & 44.10 \\
\hline \multicolumn{5}{|l|}{ Water content, $\%$} \\
\hline 0.3 Bars & 16.84 & 15.77 & 15.92 & 14.47 \\
\hline 15 Bars & 6.63 & 6.66 & 7.12 & 7.67 \\
\hline \multicolumn{5}{|l|}{ Consistence } \\
\hline Dry & Soft & Slightly hard & Hard & Very hard \\
\hline Humid & Very friable & Friable & Friable & Friable \\
\hline \multirow[t]{2}{*}{ Wet } & Not plastic & Slightly plastic & Slightly plastic & Not plastic \\
\hline & Not adhesive & Slightly adhesive & Slightly adhesive & Not adhesive \\
\hline \multicolumn{5}{|l|}{ Proctor test } \\
\hline Maximum density, $\mathrm{Mg} \mathrm{m}^{-3}$ & 1.54 & 1.66 & 1.71 & 1.69 \\
\hline \multicolumn{5}{|l|}{ Optimal compaction } \\
\hline humidity, \% & 20.7 & 18.8 & 15.41 & 16.49 \\
\hline
\end{tabular}

Table 2. Mean values of pre-work bulk density for different depths of soil profile with high and low compaction.

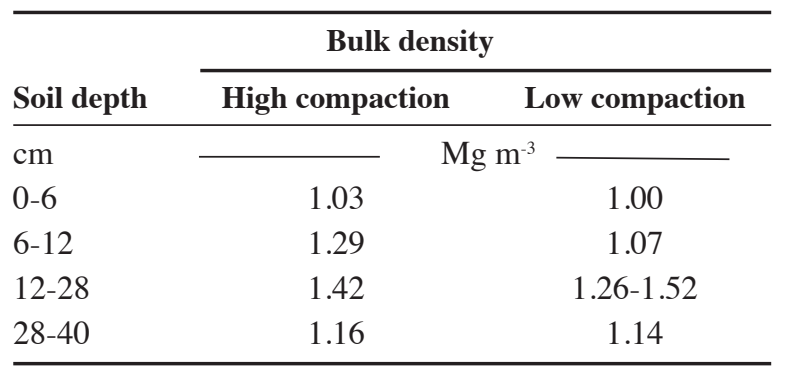

A split-plot randomized block experimental design was used with six treatments (two levels of initial compaction and three soil water contents) and four replicates: LCDS, LCHS, LCWS, HCDS, HCHS, and HCWS. Levels of soil water were obtained naturally from rainfall during the spring season. The DS condition was obtained near the end of the dry winter before the start of the rainy period. On the other hand, the HS and WS situations were obtained after precipitations of different magnitudes and frequencies that generated the desired edaphic water content condition to carry out this experiment. Experimental plots were 3 x 40 $\mathrm{m}$ and showed evidence of harvest residues from previous crops. Statistical analysis by the SAS 6.11 (Westfall et al.,
1999) program included the Tukey and Welsch multiple comparison tests (Westfall et al., 1999) to compare means at a $95 \%$ significance level.

All treatments received only one soil loosening operation with a winged scarifier similar to the "zero plowshare" prototype (Cisneros et al., 1998) (Figure 1), attached to the frame of a moldboard plow and five shares with $0.305 \mathrm{~m}$ spacing.

Tillage depth (TD) and disturbed soil area (DA) were evaluated by profilometry (Balbuena et al., 2009). Tractive effort (F) was recorded with a load cell (model t 1040, Maywood Instruments, Berkshire, England) of $34.3 \mathrm{kN}$ capacity inserted between the tractor and the implement and connected to a force integrator (model T60, LYP, La Plata, Argentina). With this variable and speed, power consumed in the traction (P) was obtained, and tillage energy efficiency or specific resistance (SR) was estimated as tractive effort/tilled area (Godwin, 2007).

\section{RESULTS AND DISCUSSION}

\section{Tractive effort (F)}

Both the presence of the densified layer and soil water content had a significant effect on tractive effort (Table 3), producing lower $\mathrm{F}$ with lower bulk density and a higher soil water content, coinciding with the tendency observed 

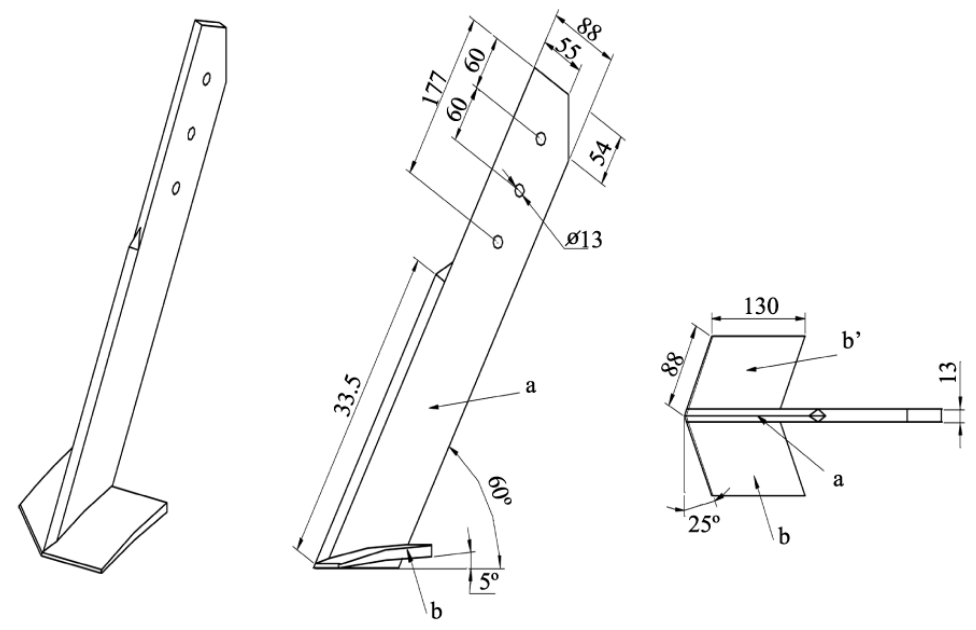

Figure 1. Diagram of the winged scarifier "zero plowshare" tested. Measures in mm.

by Mouazen and Ramon (2002) in a sandy loam soil such as the one under study. However, these authors found that the decrease in force was produced at up to a water content of $017 \mathrm{~m}^{3} \mathrm{~m}^{-3}$, value over which the differences in $\mathrm{F}$ values were small. The lowest effort observed in this study was in WS, condition in which the soil showed a mean water content of $0.23 \mathrm{~m}^{3} \mathrm{~m}^{-3}(19 \%$ gravimetric water content and $\mathrm{BD}$ mean of $1.25 \mathrm{t} \mathrm{m}^{-3}$ ), while the highest effort was recorded in HS with $0.17 \mathrm{~m}^{3} \mathrm{~m}^{-3}$ (14\% water contet), and not in the lowest humidity condition with $0.11 \mathrm{~m}^{3} \mathrm{~m}^{-3}(9 \%$ water content) as observed by those authors.

This behavior was unexpected if you also consider results obtained by Schjønning (1991), who evaluated the shear strength for different types of soils and found that resistance increased in all cases when humidity decreased, and with the tendency observed by Cholaky (2003) for similar conditions to those under study in which the mechanical resistance had values lower than 1 MPa in WS, slightly higher in the HS unit, and extreme values in DS greater than $20 \mathrm{MPa}$.

The lowest force exerted in the WS condition could be attributed to the effect of high water content exerted on cohesion (Mouazen et al., 2002), defining a decrease of this shear strength component. However, these results differed from those found by Camacho-Tamayo and Rodríguez (2007) working in a loam soil (22\% clay) with three soil water contents $\left(0.05,0.12\right.$, and $\left.0.15 \mathrm{~g} \mathrm{~g}^{-1}\right)$ who observed that the highest F occurred when the soil showed the lowest and the highest evaluated water content, attributing it, in the first case, to the increase in cohesion force, and in the second case, to soil adhesion force. The lower soil clay content under study, as compared to the experiment by these authors, could explain the observed differences between both studies.
The unexpected behavior of $\mathrm{F}$ as a function of soil water content, especially observed in LC would indicate the necessity to study more in depth the mechanical properties of sandy loam soils with variations in their water content. It would be convenient to broaden the range of humidity values under evaluation since the friable consistence state which is considered optimal for this type of tillage covers a range of humidity fluctuating around field capacity (16\%), and coinciding in some profile thicknesses with the optimal water content for soil compaction (Table 1).

In $\mathrm{HC}$, the increase of cohesion and the internal friction angle, especially in DS, resulting from the high and homogeneous BD in the 12 to $28 \mathrm{~cm}$ thickness, were possibly the causes of the higher effort with regard to LC (Mouazen et al., 2002). In LC, the irregular distribution of the high BD sectors associated with those of low BD allowed tillage with lower tractive force demand than in HC. These results coincide with those observed by Mouazen and Ramon (2002), who state that the higher the degree of compaction in a sandy loam soil, the higher F must be to carry out the decompaction operation. These results could be related to the explanation given by Schjønning (1991), who observed that cohesion of disturbed soils was lower than in undisturbed soils, conditions which could be similar to the LC and HC profiles, respectively. To this effect, Balbuena et al. (2009) state that the F and power demand of subsoilers and decompacters are subject to notable variations as a consequence of the resistance of the hardened layers on which they need to work. Regarding these results, working in similar conditions as those under study, Cholaky (2003) evaluated the pre-work penetration resistance (PR) of $\mathrm{HC}$ and LC, observing lasting structural characteristics in the disturbed situation that defined a lower resistance than in $\mathrm{HC}$. 
Table 3. Mean tractive effort (F) used as a function of soil compaction and soil water content.

\begin{tabular}{|c|c|c|c|c|}
\hline \multirow[b]{3}{*}{ Water content } & \multicolumn{4}{|c|}{ Tractive effort } \\
\hline & \multicolumn{4}{|c|}{ Compaction level } \\
\hline & $\mathrm{HC}$ & LC & Mean & $\mathrm{CV}$ \\
\hline & & $\mathrm{kN}$ & 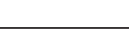 & $\%$ \\
\hline WS & 25.980 & 21.464 & $23.722 \mathrm{a}$ & 13.5 \\
\hline HS & 30.423 & 27.067 & $28.745 c$ & 8.3 \\
\hline DS & 29.152 & 22.124 & $25.638 b$ & 19.4 \\
\hline Mean & $28.520 b$ & $23.552 \mathrm{a}$ & & \\
\hline $\mathrm{CV}, \%$ & 8.0 & 13.0 & & \\
\hline
\end{tabular}

Distinct letters in the same row indicate differences between compaction levels and in the same column between humidity conditions according to multiple comparisons test at $95 \%$.

HC: high compaction; LC: low compaction; WS: wet soil; HS: humid soil; DS: dry soil; CV: coefficient of variation.

\section{Disturbed soil area (DA) and tillage depth (TD)}

The disturbed soil area was influenced by BD and soil water content at tillage. The highest DA in the HS condition in both compaction levels (Table 4) would allow to partly explain the higher tractive effort recorded in this humidity condition with regard to the rest, in particular with DS of HC with which it differed significantly.

Results of DA would not concur with those presented by Sasaki et al. (2007), who evaluated the disturbed area for a subsoiling operation in sandy clay loam and clay soils, observing that DA decreased with soil water content, variation which was not observed in this experiment in none of the compaction levels, and with no significant differences between soil water contents except for DS of HC that differed from WS and HS. In accordance with Godwin (2007), this difference could be attributed to the relationship between the clay content and soil humidity at tillage which influences its fissuring pattern in such a way that the soil of this experiment, with a lower clay content than the experiment carried out by those researchers, would have followed a pattern of brittle failure in all evaluated humidity conditions, while in that experiment, it is probable that with high water levels, plowing will not have been carried out according to this pattern but according to a plastic flow pattern, in this way decreasing DA as water in the soil increased. On the other hand, the same authors evaluated soil water content to carry out the subsoiling operation and established the optimal water interval to generate the highest soil DA between $80 \%$ water content at field capacity and the permanent wilting point as higher and lower limits, respectively, ranging from 0.07 to $0.13 \mathrm{~cm}^{3} \mathrm{~cm}^{-3}$ for the sandy clay loam soil, approximately coinciding with the range of this experiment for the thickness of the compacted layer (Table 1). This humidity interval would include or would be near the water contents corresponding to DS and HS which could partly explain the similar behavior of these humidity levels in LC, but not so with WS.

Neither did observed results coincide with those presented by Camacho-Tamayo and Rodríguez (2007), who found that the work done by a plow with rigid chisels produced higher DA with a higher humidity content $\left(0.15 \mathrm{~g} \mathrm{~g}^{-1}\right.$ compared to

Table 4. Disturbed area (DA) and mean tillage depth (TD) as regards soil compaction and soil water content.

\begin{tabular}{|c|c|c|c|c|}
\hline \multirow[b]{3}{*}{ Humidity condition } & \multicolumn{2}{|c|}{ Disturbed area } & \multicolumn{2}{|c|}{ Tillage depth } \\
\hline & \multicolumn{4}{|c|}{ Compaction level } \\
\hline & HC & LC & HC & LC \\
\hline & \multicolumn{2}{|c|}{$\mathrm{cm}^{2}$} & 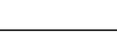 & 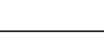 \\
\hline WS & $3103.80 \mathrm{a}$ & $3230.60 \mathrm{a}$ & $27.00 \mathrm{a}$ & $28.00 \mathrm{a}$ \\
\hline HS & $3351.50 \mathrm{a}$ & $3501.60 \mathrm{a}$ & $29.00 \mathrm{a}$ & $30.30 \mathrm{a}$ \\
\hline DS & $2684.10 \mathrm{~b}$ & $3304.60 \mathrm{a}$ & $23.20 \mathrm{~b}$ & $28.40 \mathrm{a}$ \\
\hline Mean & 3046.47 & 3345.60 & 26.35 & 28.86 \\
\hline $\mathrm{CV}, \%$ & 11.1 & 4.2 & 1.2 & 1.1 \\
\hline
\end{tabular}

Distinct letters in columns indicate differences between humidity conditions according to multiple comparisons test at $95 \%$. HC: high compaction; LC: low compaction; WS: wet soil; HS: humid soil; DS: dry soil; CV: coefficient of variation. 
0.05 and $0.12 \mathrm{~g} \mathrm{~g}^{-1}$ ), while the plow with vibratory chisels generated higher DA in the intermediate humidity level.

In both compaction situations, there were no differences between the mean effective tillage depth of the distinct soil water levels, except for DS at HC where TD was lower than WS and HS (Table 4). Results indicated that in this condition, the shares of the tool did not succeed in covering the total thickness of the densified layer whose base, according to what was observed in the plow profile analysis, fluctuated around a $28 \mathrm{~cm}$ depth. On the other hand, in all LC cases, tillage depth disturbed up to the compacted layer. These results did not respond to the tendencies observed by CamachoTamayo and Rodríguez (2007) for a humidity range between 0.05 and $0.15 \mathrm{~g} \mathrm{~g} \mathrm{~g}^{-1}$, whereas for a vibratory chisel, TD increased as soil humidity increased, while for work with a rigid chisel, TD was lower in the highest water level.

The profilometry study to evaluate DA and TD indicated, in all cases except in DS at HC that TD was uniform, showing an adequate overlap of the work carried out for each share of the implement. To this effect, if the relationship of distance between active organs and mean tillage depth cited by Balbuena et al. (2009) is approximately $1.4 \pm 25 \%$ times tillage depth, in LC was 1.04 and was 1.09 in $\mathrm{HC}$ without considering DS, for which it could be afirm that these values are found in the extreme lowest limit of the optimal range of spacing between active organs of decompacters.

In DS of $\mathrm{HC}$, TD, which was very irregular, as well as DA were lower than in the rest of the treatments, evidence, on the one hand, that homogeneousness of the compaction state of the plow profile added to the high resistance that the soil acquires at this water content, represented a physicalmechanical barrier for the penetration of the implement, and on the other hand, the existence of a close relationship between TD and DA. According to McKyes (1985), the lowest tractive effort in DS with regard to HS could be attributed to differences in operational conditions (depth and tillage speed) as a product of the state of the land or to differences in the final state of the soil (disturbed area, changes in aggregate diameter, and $\mathrm{BD}$ ).

The behavior of TD and DA did not show a clear relationship with regard to $\mathrm{F}$ values since the differences found in this last variable did not correspond to significant differences in the first two. This behavior would not concur with that found by Mouazen and Ramon (2002) who observed that tractive effort increased with tillage depth. However, in accordance with Godwin (2007) regarding small variations in tillage depth can produce great differences in tractive effort, it could explain, at least partly, the highest F in HS with regard to WS and DS, because it presents in both compaction levels a higher TD and DA in terms of absolute value. In DS of HC, though there was a decrease in tractive effort due to lower TD and DA with regard to the other two water contents, it did not show the expected magnitude, which could be attributed to the effect of high soil resistance to this soil water content according to Mouazen and Ramon (2002).

\section{Specific resistance $(\mathrm{SR})$ and power $(\mathrm{P})$}

Soil water content at tillage influenced SR. In HC, DS showed a significantly higher SR than the other two humidity situations (Table 5), thus indicating that work carried out under these conditions was the least energy efficient, corroborating Godwin (2007) who suggests that specific resistance is a better indicator than tractive effort of the overall tillage result. This compaction condition and soil water content produced scarce tillage depth and the smallest disturbed soil area, resulting also in inefficient tillage since part of the densified layer was not modified.

The mechanical behavior observed in DS of HC impeded the equipment from penetrating in the soil up to the adequate depth. According to Arvidsson et al.

Table 5. Specific resistance $(\mathrm{SR})$ and power input $(\mathrm{P})$ related to soil compaction and soil water content.

\begin{tabular}{|c|c|c|c|c|}
\hline \multirow[b]{3}{*}{ Humidity condition } & \multicolumn{2}{|c|}{ Specific resistance } & \multicolumn{2}{|c|}{ Power input } \\
\hline & \multicolumn{4}{|c|}{ Compaction level } \\
\hline & HC & LC & HC & LC \\
\hline & \multicolumn{2}{|c|}{$\mathrm{N} \mathrm{cm}^{-2}$} & \multicolumn{2}{|c|}{$\mathrm{kW}$} \\
\hline WS & $8.4 \mathrm{~b}$ & $6.7 \mathrm{~b}$ & $42.4 \mathrm{~b}$ & $35.8 \mathrm{c}$ \\
\hline HS & $9.1 \mathrm{~b}$ & $7.7 \mathrm{a}$ & $50.0 \mathrm{a}$ & $45.3 \mathrm{a}$ \\
\hline DS & $11.0 \mathrm{a}$ & $6.7 b$ & $42.3 b$ & $40.1 \mathrm{~b}$ \\
\hline Mean & 9.51 & 7.03 & 44.9 & 40.4 \\
\hline $\mathrm{CV}, \%$ & 1.92 & 2.60 & 9.9 & 11.8 \\
\hline
\end{tabular}

Means followed by distinct letters in a column indicate statistically significant differences between humidity conditions according to multiple comparisons test at $95 \%$.

HC: high compaction; LC: low compaction; WS: wet soil; HS: humid soil; DS: dry soil; CV: coefficient of variation. 
(2004), this could be attributed to the high cohesion that the compacted layer presented along with the inherent limitations of the "zero plowshare" design, the attack angle of the wings, or the lack of a plowshare that increases its penetration capacity.

In $\mathrm{HC}$, despite a greater tractive effort in HS than in the rest of the humidity levels, SR did not differ from WS, that is, both situations expended similar energy to fragment each unit of tilled area which could have influenced these result of SR, because DA was greater in HS than WS. This behavior differed from that observed by Arvidsson et al. (2004), who suggest that the highest energy efficiency of different tillage implements is produced in humid soil because it generates the greatest proportion of small aggregates and the least energy expenditure to fragment the soil. However, and according to Cholaky et al. (2002) who worked in the same assay as the one in this study, a change occurred in the weighted mean diameter of aggregates of the original densified layer from 8.9 to $1.8 \mathrm{~cm}$ and from 7.9 to $3.34 \mathrm{~cm}$ in HS and WS, respectively, and a change in the proportion of small aggregates at $11 \mathrm{~mm}$ from $11 \%$ to $61.5 \%$ and $39 \%$ in HS and WS, respectively. That is, there were differences in the final state shown by the soil after tillage between both humidity situations.

Results analyzed until now have also differed from those obtained by Camacho-Tamayo and Rodríguez (2007) who observed that SR was higher as soil water content increased due to the fact that the high clay content, the soil suffered plastic deformation below the critical depth, following a plstic flow pattern. This behavior was not observed in this experiment, neither for soil texture nor for geometric characteristics of the tool.

Absolute values of SR indicated that tillage was more efficient in LC than in HC. Tillage in LC-HS presented a significantly higher SR than in the other two humidity situations, thus indicating that HS was less efficient. Soil in WS offered low resistance and was not very cohesive due to the high water content that characterized this treatment and the partial persistence of the loosening effect produced by previous decompaction tillage, while in DS this last aspect could have generated a lower cohesion than in $\mathrm{HC}$ at the same soil water content. However, if you consider the final state of the tilled soil, in accordance with Cholaky et al. (2002), tillage in HS produced a change in the weighted mean diameter of aggregates of the original densified layer from 9.5 to $1.9 \mathrm{~cm}$, while in WS and DS, this change was from 12.2 to $4 \mathrm{~cm}$, and from 8.3 to 1.6 $\mathrm{cm}$, respectively and the proportion of small aggregates at $11 \mathrm{~mm}$ decreased from $11 \%$ to $55.3 \%, 53.9 \%$ and $28.4 \%$ in HS, DS, and WS, respectively. Therefore, this would indicate, in accordance with Di Prinzio et al. (1999), that tillage in WS was not the most efficient if it is explained as a way of balancing energy used for each unit of tilled area and the agronomic result obtained in the physical condition of the profile.

Regarding power required for tillage in the different treatments, in $\mathrm{HC}$, mean $\mathrm{P}$ increased by $11 \%$ with regard to LC (Table 5). If you consider that the mean tillage speed in all treatments was $6 \mathrm{~km} \mathrm{~h}^{-1}$, it clearly appears that the observed variation in tractive effort had an evident effect on this variable. In HC, HS presented a significantly higher $\mathrm{P}$ than WS and DS which did not differ one from the other. In LC, a higher variation of $\mathrm{P}$ was observed as a function of soil water content than in $\mathrm{HC}$, producing a decreasing tendency of power of HS, DS, and WS in that order, can also associating with the behavior observed in $\mathrm{F}$.

\section{CONCLUSIONS}

In high compaction and dry soil conditions, tillage with a winged decompacter is inefficient, consuming a lot of energy to fracture the profile up to a depth that is scarce and irregular.

Independently of the initial compaction profile, tillage carried out in wet soil conditions shows a lower specific resistance, though this does not mean that it produces an adequate degree of soil fracture.

In the high compaction profile, tillage carried out in humid soil was efficient because it required low energy to produce the profile fracture up to the desired depth.

When the initial situation has previous tillage with "zero plowshare", both the state of humid and dry soil allow efficient tillage, whether for required energy or profile fragmentation up to an adequate depth.

Specific resistance is not a synthesis variable of overall tillage efficiency due to the fact that it only contemplates the energy consumed and not the final physical condition of the plow profile.

\section{RESUMEN}

Desempeño a campo de un escarificador alado en función de la compactación y el contenido de agua del suelo. El estado inicial del suelo, aspectos operativos y de diseño de las herramientas, influyen sobre la eficiencia de una labor de descompactación. El objetivo de este trabajo fue evaluar el desempeño de un escarificador alado en función de la compactación y humedad edáfica. La experiencia se realizó en un Hapludol típico. Los tratamientos abarcaron dos niveles de compactación: alta (HC) y baja (LC) y tres contenidos de agua del suelo, mojado (WS), húmedo (HS) y seco (DS), con 9; 14 y $19 \%$ de humedad, respectivamente. El diseño experimental fue en parcelas subdivididas en bloques al azar. Se evaluó 
esfuerzo de tracción, área disturbada, profundidad de trabajo, resistencia específica y potencia. Los resultados indicaron que en $\mathrm{HC}$ el esfuerzo de tracción fue $17 \%$ mayor que en LC y en ambos casos resultó mayor en HS que en WS y DS. La resistencia específica en $\mathrm{HC}$ fue igual a 8; 9 y $11 \mathrm{~N} \mathrm{~cm}^{-2}$ en WS, HS y DS, respectivamente, y en LC fue igual a $7 ; 8$ y $7 \mathrm{~N} \mathrm{~cm}^{-2}$ en similares contenidos de agua del suelo, respectivamente. En HC-DS la profundidad de trabajo fue escasa e irregular, no así en el resto de los tratamientos. La resistencia específica no fue un indicador adecuado de la eficiencia global de labor, al no considerar el estado final de la condición física del perfil. En HC-HS mostró la mayor eficiencia global de la labor, mientras que en LC lo hicieron HS y DS.

Palabras clave: ingeniería agrícola, escarificador alado, densidad aparente, contenido de agua, compactación de suelo.

\section{LITERATURE CITED}

Agencia Córdoba Ambiente-INTA. 2006. Recursos naturales de la provincia de Córdoba. Los suelos, nivel de reconocimiento 1: 500.000. 612 p. Agencia Córdoba Ambiente-Instituto Nacional de Tecnología Agropecuaria (INTA), Estación Experimental Manfredi, Córdoba, Argentina.

Arvidsson J., T. Keller, and K. Gustafsson. 2004. Specific draught for mouldboard plough, chisel plough and disc harrow at different water contents. Soil Tillage Res. 79:221-231.

Balbuena, H.R., G.F. Botta, y E.R.D. Rivero. 2009. Herramientas de labranza para la descompactación del suelo agrícola. 216 p. Orientación Gráfica Editora, Buenos Aires, Argentina.

Camacho-Tamayo, J.H., y G.A. Rodríguez. 2007. Evaluación de implementos de labranza a diferentes velocidades de operación y contenidos de agua del suelo. Agric. Téc. (Chile) 67:60-67.

Cholaky, C.G. 2003. Efectividad y persistencia de una labor de descompactación con subsolador alado, en función de la compactación y humedad antecedente. 196 p. Tesis M.Sci. Universidad Nacional de Río Cuarto, Facultad de Agronomía y Veterinaria, Río Cuarto, Argentina.

Cholaky, C.G., J.M. Cisneros, y R.H. Balbuena. 2002. Descompactación de suelos del área núcleo manisera de Córdoba con subsolador alado, en función de la humedad y compactación antecedente. p. 80. XVIII Congreso Argentino de la Ciencia del Suelo, Puerto Madryn. 16-19 de abril de 2002. Asociación Argentina de la Ciencia del Suelo, Puerto Madryn, Argentina.
Cisneros, J.M., A. Cantero, J. Marcos, A. Degioanni, E. Bricchi, O. Giayetto, et al. 1998. Comportamiento de un subsolador alado adaptable a implementos de uso común. p. 128-134. In Balbuena R., S.H. Benez, y D. Jorajuría (eds.) Ingeniería rural y mecanización agraria en el ámbito de Latinoamérica. Editorial de la Universidad de La Plata, La Plata, Argentina.

Desbiolles, J.M.A., R.J. Godwin, J. Kilgour, and B.S. Blackmore. 1997. A novel approach to the prediction of tillage tool draught using a standard tine. J. Agric. Eng. Res. 66:295-309.

Di Prinzio, A.P., S.N. Behmer, J.A. Irisarri, G.L. Striebeck, y P. Chiementon. 1999. Demanda energética y calidad de labor para arados cinceles. Agro-Ciencia 15:231234.

Di Prinzio, A.P., S.N. Behmer, G.L. Striebeck, y J.A. Irisarri. 2001. Influencia de las rejas aladas de un subsolador combinado sobre el rendimiento de la labor. Agric. Téc. (Chile) 61:235-240.

Godwin. R.J. 2007. A review of the effect of implement geometry on soil failure and implement forces. Soil Tillage Res. 97:331-340.

McKyes, E. 1985. Soil cutting and tillage. Developments in agricultural engineering 7. Chapters 3 and 4. p. 87104. Elsevier Sci. Publishers B.V., Amsterdam, The Netherlands.

Mouazen, A.M. 2002. Mechanical behaviour of the upper layers of a sandy loam soil under shear loading. J. Terramechanics 39:115-126.

Mouazen, A.M., and H. Ramon. 2002. A numericalstatistical hybrid modeling scheme for evaluation of draught requirements of subsoiler cutting a sandy loam soil, as affected by moisture content, bulk density and depth. Soil Tillage Res. 63:155-165.

Mouazen, A.M., H. Ramon, and J. De Baerdemaekerb. 2002. Effects of bulk density and moisture content on selected mechanical properties of sandy loam soil. Biosyst. Eng. 83:217-224.

Ressia, J.M., G.O. Mendivil, R. Balbuena, H. Chidichimo, y M.Asborno. 2000. Efecto de los sistemas de labranza sobre la resistencia a la penetración y humedad del suelo y la producción de maíz (Zea mays L.) AgroCiencia 16:197-205.

Sasaki, C.M., J.L. Goncalves, and A.P. da Silva. 2007. Ideal subsoiling moisture content of Latosols used in forest plantations. For. Ecol. Manage. 243:75-82.

SAGyP-CFA. 1995. El deterioro de las tierras en la República Argentina-Alerta Amarillo. 287 p. DUO/ Comunicación Visual, Capital Federal, Buenos Aires, Argentina. 
Schjønning, P. 1991. Soil mechanical properties of seven Danish soils. Internal Report $\mathrm{N}^{\circ}$ S2176. Danish Institute of Agricultural Sciences, Research Centre Foulum, Tjeje, Denmark.

Uberto, M.E., J.M. Cisneros, C.G. Cholaky, L. Verri, G. Cerioni, y G. Santa. 2004. Rotaciones y labranzas en maní. Recuperación de propiedades físicas y productividad de las tierras. p. 6-7. In XVIII Jornada Nacional de Maní, Gral. Cabrera. 27 de septiembre de 2004. Centro de Ingenieros Agrónomos Gral. Cabrera y Zona-Instituto Nacional de Tecnología Agropecuaria (INTA), Gral. Cabrera, Córdoba, Argentina.
Westfall, P.H., R.D. Tobias, D. Rom, R.D. Wolfinger, and Y. Hochberg. 1999. Multiple comparisons and multiple test using the SAS System. 397 p. SAS Institute, Cary, North Carolina, USA. 